\title{
Research on Inventory Cost Control of China Resources Vanguard
}

\author{
Yangyan Li \\ Xijing University \\ Xi'an, China 710123
}

\begin{abstract}
This paper takes the inventory cost control of chain supermarket as the research topic. By reading relevant theoretical knowledge about cost control and inventory management, combined with domestic and foreign scholars' research on inventory cost control, it makes the summary from practical application. Also, it provides theoretical basis for analyzing the inventory cost control of China Resources Vanguard. The two foreign large-scale chain supermarkets of Wal-Mart and Carrefour are compared and analyzed with comparative analysis. It is concluded that the foreign retailers in selling goods at low prices is to establish a good strategic partnership, attach importance to process management, and improve information systems and standardize the work flow. The inductive deduction method was used to analyze the inventory cost control of China Resources Vanguard Supermarket in terms of operation status and inventory cost control. It is found that there are problems in the total inventory cost, inventory order cost and inventory shortage cost, resulting in low turnover rate, high inventory holding cost and unsatisfactory procurement cost. This has affected the pricing of commodities and reduced the core competitiveness of enterprises. Therefore, in combination with the above problems, this paper proposes some suggestions for inventory cost control based on the current actual situation of China Resources Vanguard. It not only has practical significance for inventory cost control of China Resources Vanguard, but also has certain reference value for the inventory cost management of China's overall chain retail industry.
\end{abstract}

Keywords-chain supermarket; China Resources Vanguard; inventory cost control

\section{INTRODUCTION}

\section{A. Background and Significance}

In recent years, under the background of the development of international economic globalization, the domestic economy has continued to grow, and consumer demand has also been rising. Major commercial chain companies have ushered in a period of rapid development. The industry has experienced long-term development and has formed a variety of retail forms, of which supermarkets are one of the fastest growing segments of retail. Supermarkets have now become the most basic form of China's retail industry. From the actual situation, people's lives are inseparable from supermarket chains. Supermarket operation is to reserve a large amount of goods for consumers to purchase, and the process management of goods from procurement to sale is called inventory management.

Any enterprise is for profit. To increase the profit of the company, it is necessary to reduce the cost. Inventory cost management is an important part of the cost control of supermarket chains. Based on the above statement, the research on the optimization plan of inventory cost control of China Resources Vanguard Supermarket has the following theoretical significance and practical value. 1. Using the theory of inventory cost control, we can extract the key points of inventory cost control of chain supermarkets, and then formulate effective measures to control the inventory cost of chain supermarkets from the theoretical level. 2. From a practical point of view, in the face of the layout of various retail giants in the Chinese market, we should deeply study the optimization program of inventory cost control of China Resources Vanguard. We can effectively grasp the actual situation of its inventory cost management, and find the defects and shortcomings of current inventory cost control, improve the scientific nature of the development of cost control measures, reduce the inventory cost of enterprises, accelerate the inventory turnover rate, reduce the occupation of working fund, and significantly improve the inventory control of China Resources Vanguard Chain Supermarket, stabilize the core competitiveness of enterprises, and maximize the consumer's consumer demand.

\section{B. Literature Review}

The theory of foreign inventory cost control originated in the early 20th century. Influenced by the second industrial revolution, the early research of foreign scholars was to adapt to the development model of Western capitalism, mainly focusing on the management method of inventory. In 1913, Harris first proposed the EOQ model [1], that is, the economic batch ordering equation. This model has some limitations, however, it tells us how to balance costs and calculate the order quantity that minimizes the total cost. Chakrabarty T (1999) introduced the stochastic supply index when studying the EOQ model, and obtained the relationship between the best economic order quantity and the enterprise inventory cost control. And then, he extended to improve the scope of enterprise management [2]. Robert and Steve (2004) made a standard definition of the ABC Activity-Based Costing Act in the "ABC Activity-Based Costing Act". In 1999, Peter Dirk conducted a more detailed analysis of the activity-based costing method [2]. The study of J. Michalska 
D. Szewieczek (2007) makes the ABC approach applicable to different types of industries [3].

Domestic scholars' research on inventory cost control started relatively late in foreign countries, mainly focusing on inventory cost accounting and internal control of enterprises. It is also further refined and summarized on the basis of research by foreign scholars. Zhang Liping (2009) takes the inventory cost control problem of HB Company based on supply chain management as the research object, and makes an in-depth study on the defects and shortcomings of HB Company's inventory cost control, and comprehensively controls the inventory cost of HB Company by using $\mathrm{ABC}$ classification management method. The actual application effect is more significant [3]. Dong Hui (2013) used Excel in the study of enterprise inventory cost control using EOQ economic batch model. By using Excel to conduct empirical research on EOQ model, it can not only effectively reduce the inventory cost of enterprises, but also improve the utilization rate of supermarket funds and the corporate profits. [7]

\section{ENTERPRISE INVENTORY COST CONTROL THEORY}

\section{A. Cost Control Theory}

The cost control theory mainly refers to using relevant theories and methods of management to control the actual operating costs of enterprises to achieve the purpose of optimizing corporate capital investment and resource utilization. Cost control is a cost management goal established in advance in certain period. It refers to a series of precautions and adjustments for the factors and conditions that affect the cost within the authority scope of cost control subject before the production cost and during the cost control process. It can ensure management behavior achieving cost management objectives.

\section{B. Inventory Cost Control}

1) Inventory cost: The so-called inventory cost mainly refers to the sum of various costs invested in the inventory, that is, all the enterprise expenses in terms of inventory. The accounting standard of an enterprise makes the explanation on inventory costs that inventory cost is the sum of procurement, processing and other costs. In theory, inventory costs primarily include all direct or indirect expenses incurred from the purchase of goods to the location and status of the goods that can be sold. In general, the cost of goods can be clearly stated through specific resolution, first-in, first-out, weighted average, and individual valuation. These methods are commonly used by enterprises. Different methods are use in different conditions. Each has its own advantages and disad'vantages.

\section{2) Inventory cost management}

a) Inventory decision: The purpose of inventory decisions is to control the inventory holding costs of the business. On the basis of quantitative analysis of materials, enterprise management personnel clarify the materials that need to be in inventory, the materials that are not in stock, the inventory levels of different products, the turnover ratio and the distribution status, and then determine the cost of holding inventory.

b) Determining the order method of the stock: The ordering method for determining inventory is to control the inventory acquisition cost of the enterprise. The management personnel of the enterprise must know the ordering point, ordering period and order quantity. The cost of holding the inventory is effectively controlled. For example, if the goods need to be purchased in Spain, the bulk purchase should be controlled once a month.

c) Supply and demand forecast: Supply and demand forecasts are intended to control the shortage cost of inventory. Conducting more accurate demand forecasting is one of the most important aspects of inventory management, mainly including product production and sales planning. When conducting business management, enterprises should not only develop a scientific inventory management model based on the product characteristics of the enterprise, but also adopt different strategies for inventory products, and subdivide different types for management. That is to use ABC classification method for management.

3) Safety inventory management: For enterprises, setting up safety inventory not only can the out-of-stock problems be effectively prevented, but also the reasonable setting of safety inventory is also beneficial to the control of the total inventory cost of enterprises. The quantitative order method and the regular order method have different scope of application. Generally speaking, the quantitative ordering method applies to a small number of species and takes up a large capital, which is suitable for Class A commodities that need to be managed in a key manner. The regular ordering method applies to a large number of species and takes up less funds, which is suitable for general management of Class B and Class C commodities. The enterprises should make reasonable choices in safety inventory management.

\section{THE STATUS AND PROBLEMS OF INVENTORY COST CONTROL OF CHINA RESOURCES VANGUARD}

\section{A. Overview of China Resources Vanguard Supermarket}

Founded in 1984, China Resources Vanguard has played a leading role in the retail industry through continuous efforts over the past 30 years. It has been adhering to the concept of comprehensively improving the quality of life of consumers, advocating and opening up a green and healthy lifestyle, providing consumers with quality, value-for-money, safe goods and services to maximize the consumer's various shopping needs. As of 2016, the sales revenue of China Resources Vanguard's self-operated stores exceeded 100 billion, and the number of stores increased to nearly 3,300. In 2014, China Resources Vanguard and TESCO China merged to achieve leap-forward development. After completing the joint venture target, China Resources Vanguard has opened self-operated stores in 240 cities in 30 provinces, autonomous regions, municipalities and special 
administrative regions in China, with a total of 260,000 employees.

After years of development, China Resources Vanguard has gradually developed into a giant in the domestic retail industry, and its retail industry is already in a relatively leading position. Through the investigation of China Resources Vanguard Supermarket, we understand that they have established a relatively sound organizational structure. The specific organizational structure is shown in the following "Fig. 1":

China Resources Vanguard

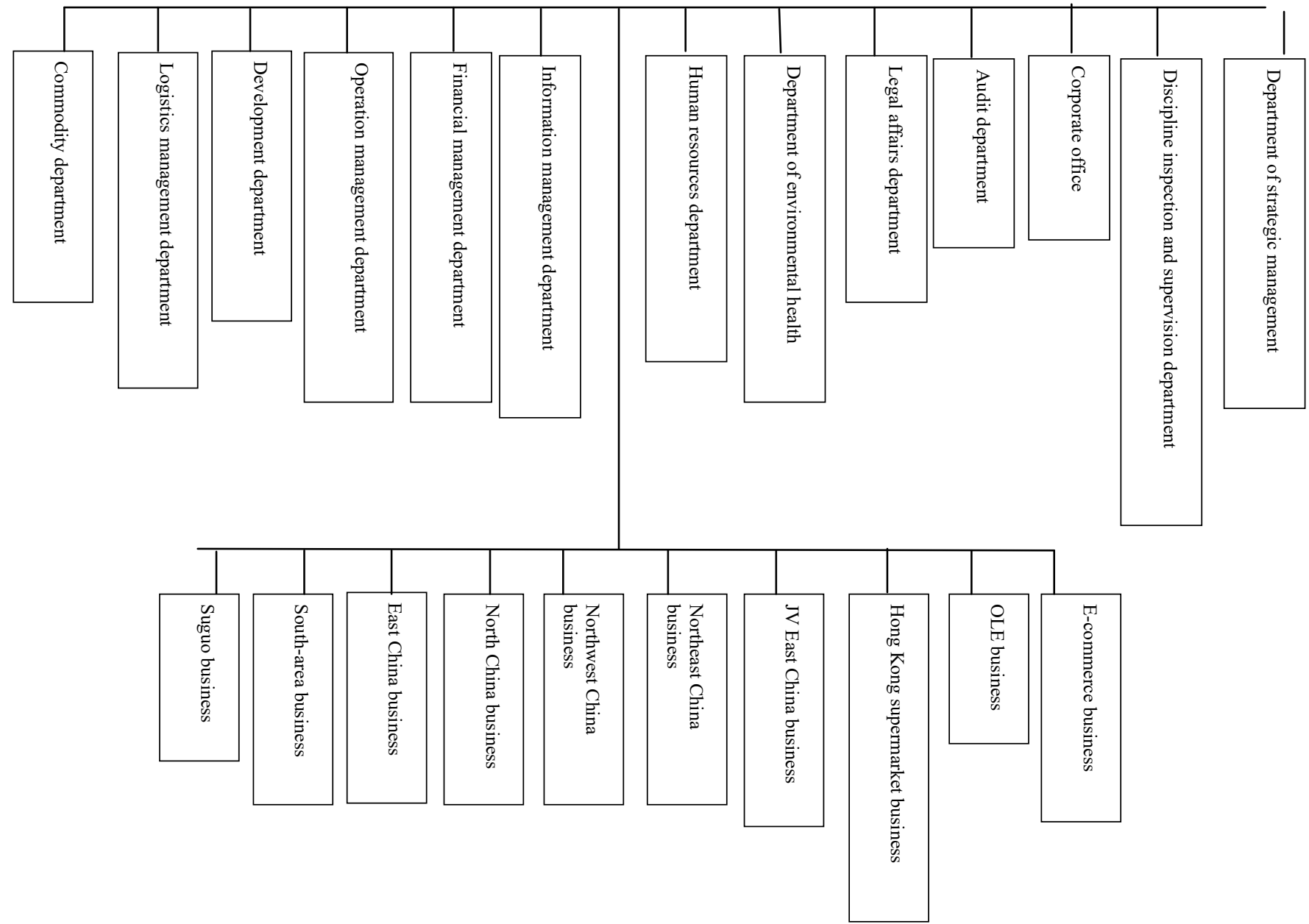

Fig. 1. Organization structure of China Resources Vanguard.

\section{B. Summary of the Operation of China Resources Vanguard}

The operating status reflects the income and cost of China Resources Vanguard Supermarket. It not only reflects the current operating performance, but also reveals the future development potential. Therefore, we can further understand the management status of China Resources Vanguard Supermarket.

1) Analysis of operating income and cost: The income data of China Resources Vanguard Chain Supermarket in 2015 and 2016 are shown in the following table:
TABLE I. COMPARISON OF OPERATING INCOME AND COST OF CHINA RESOURCES VANGUARD SUPERMARKET IN 2015 AND 2016

\begin{tabular}{|l|c|c|c|}
\hline \multicolumn{1}{|c|}{$\begin{array}{c}\text { Expense } \\
\text { name }\end{array}$} & total in 2016 & Data of last year & $\begin{array}{c}\text { Adjustmen } \\
\text { t range }\end{array}$ \\
\hline $\begin{array}{l}\text { Operating } \\
\text { income }\end{array}$ & $421,448,295.61$ & $367,268,029.55$ & $14.75 \%$ \\
\hline operating cost & $337,854,375.72$ & $295,068,888.10$ & $14.50 \%$ \\
\hline \multicolumn{3}{|c|}{ a. (unit: yuan) }
\end{tabular}

As can be seen from the data in the above "Table I", China Resources Vanguard Supermarket maintains relatively good operating results, and its operating income in 2016 increased by $14.75 \%$ compared with that in 2015 . On the one hand, this proud achievement is due to the opening of many 
new stores, which has led to an increase in total operating income. On the other hand, it also benefits from the increase in actual revenues of various stores. At the same time, it cannot be ignored that the operating cost of China Resources Vanguard Supermarket is also growing at the same proportion. To a certain extent, this also shows that China Resources Vanguard Supermarket currently lacks effective measures in the control of operating costs, the company's operating costs are still at a relatively high level, and the growth rate is relatively high.
2) Analysis of commodity category data: At present, China Resources Vanguard Supermarket mainly deals with different commodity categories such as fresh food, food supplies and clothing. The operating income and operating cost data of various product categories of China Resources Vanguard Supermarket in 2016 are as shown in the following "Table II":

TABLE II. The DATA OF OPERATING INCOME AND OPERATING COST OF VARIOUS COMMODITY CATEGORIES OF CHINA RESOURCES VANGUARD SUPERMARKET IN 2016

\begin{tabular}{|c|c|c|c|c|c|c|}
\hline product type & Operating income & $\begin{array}{c}\text { Year-on-year } \\
\text { increase or } \\
\text { decrease }\end{array}$ & Operating cost & $\begin{array}{c}\text { Year-on-year } \\
\text { increase or } \\
\text { decrease }\end{array}$ & $\begin{array}{c}\text { Gross profit } \\
\text { rate }\end{array}$ & $\begin{array}{c}\text { Year-on-year rise } \\
\text { and fall }\end{array}$ \\
\hline $\begin{array}{l}\text { Fresh } \\
\text { commodities }\end{array}$ & $185,064,556.33$ & $13.53 \%$ & $161,365,601.59$ & $13.50 \%$ & $12.81 \%$ & increased by $0.02 \%$ \\
\hline Food supplies & $194,606,150.40$ & $17.43 \%$ & 158.869 .728 .42 & $17.30 \%$ & $18.36 \%$ & increased by $0.09 \%$ \\
\hline Clothing & $22,324,157.20$ & $-1.05 \%$ & $15,577,213.85$ & $-1.78 \%$ & $30.22 \%$ & increased by $0.52 \%$ \\
\hline
\end{tabular}

In the operation of China Resources Vanguard Supermarket, the operating income of fresh goods and food products accounted for a relatively high proportion, which is the main income of China Resources Vanguard Supermarket, and the proportion of clothing in it is relatively small.

\section{Inventory Cost Control of China Resources Vanguard}

In order to analyze the inventory cost control strategy of China Resources Vanguard Supermarket more comprehensively, it is necessary to understand the current situation of inventory cost control of China Resources Vanguard Supermarket.

1) Analysis of inventory turnover rate: The higher the inventory turnover rate is, the stronger the inventory liquidity and the lower the amount of funds occupied by the inventory will be. It is conducive to reducing inventory costs.

In order to fully understand the inventory turnover rate of China Resources Vanguard Supermarket, we should compare it with large foreign retail giants such as Wal-Mart and Carrefour to summarize the shortcomings in inventory turnover. The following table is the comparison of inventory turnover of China Resources Vanguard Supermarket, WalMart and Carrefour:

TABLE III. COMPARISON OF INVENTORY TURNOVER OF CHINA RESOURCES VANGUARD SUPERMARKET, WAL-MART AND CARREFOUR IN 2016

\begin{tabular}{|l|l|l|}
\hline Supermarket name & $\begin{array}{c}\text { Inventory } \\
\text { turnover rate }\end{array}$ & $\begin{array}{c}\text { Inventory } \\
\text { turnover days }\end{array}$ \\
\hline Carrefour & 9.4 & 38.3 \\
\hline Wal-Mart & 9.1 & 39.6 \\
\hline $\begin{array}{l}\text { China Resources } \\
\text { Vanguard }\end{array}$ & 7.1 & 50.7 \\
\hline
\end{tabular}

According to the data in "Table III", the inventory turnover rate of China Resources Vanguard Supermarket in 2016 is 7.1. Compared with Carrefour's 9.4 and Wal-Mart's
9.1, there is still a big gap. From the comparison of inventory turnover days, the inventory turnover days of China Resources Vanguard Supermarket have exceeded 50 days, while Carrefour and Wal-Mart's inventory turnover days are no more than 40 days. The gap is more obvious. It can be concluded that the inventory turnover rate of China Resources Vanguard Supermarket is significantly different from that of Wal-Mart and Carrefour. The inventory liquidity of China Resources Vanguard Supermarket is relatively low. Due to the low liquidity of inventory, it will inevitably lead to large inventory capital and low efficiency of capital turnover. At the same time, the inventory management costs have also increased significantly, and the cost of holding inventory has increased significantly. Therefore, in the context of China's increasingly fierce competition in the retail industry, China Resources Vanguard Supermarket needs to further increase inventory turnover and reduce inventory turnover days. This will contribute to inventory cost control.

2) Analysis of inventory and out-of-stock cost: For China Resources Vanguard Supermarket, a retail supermarket chain, the shortage of goods will mainly lead to the loss of sales and customers. Especially, in the context of the increasingly fierce competition in the domestic retail industry, the shortage of goods will inevitably make consumers go to other supermarkets to buy, which will also cause the loss of customers.

In order to reflect the out-of-stock cost of China Resources Vanguard Supermarket in a more specific way, the shortage status is investigated. The specific survey results are shown in the following table: 
TABLE IV. Statistics OF OUT-OF-STOCK SitUATION OF CHINA RESOURCES VANGUARD SUPERMARKET

\begin{tabular}{|l|l|l|l|}
\hline \multicolumn{1}{|c|}{$\begin{array}{c}\text { Commodity } \\
\text { category }\end{array}$} & $\begin{array}{c}\text { Number of } \\
\text { investigation }\end{array}$ & $\begin{array}{c}\text { Out-of-stock } \\
\text { status }\end{array}$ & $\begin{array}{c}\text { Out-of- } \\
\text { stock } \\
\text { rate }\end{array}$ \\
\hline fresh commodities & 100 & 3 & $3 \%$ \\
\hline food category & 100 & 5 & $5 \%$ \\
\hline $\begin{array}{l}\text { daily use chemical } \\
\text { category }\end{array}$ & 100 & 2 & $2 \%$ \\
\hline Others & 100 & 6 & $6 \%$ \\
\hline Total & 400 & 16 & $4 \%$ \\
\hline
\end{tabular}

Judging from the above investigations, the comprehensive out-of-stock rate of China Resources Vanguard supermarket is $4 \%$, and out-of-stock rate of WalMart and Carrefour is generally lower than $2 \%$. There is a big gap among them. However, due to the high out-of-stock rate, it will inevitably lead to an increase in the cost of outof-stocks. From the current point of view, we can't accurately measure and calculate the cost of out-of-stocks. The cost of out-of-stock is invisible and potential. The higher the out-ofstock rate is, the higher the potential cost of sales and customer loss will be. This is even more unfavorable for the cost control of China Resources Vanguard Supermarket. Therefore, in this context, China Resources Vanguard Supermarket needs to strengthen the management of out-ofstocks. Then, it can achieve effective control of out-of-stock costs.

3) The problem of inventory control of China Resources Vanguard: In recent years, the competition in the domestic retail market has become increasingly fierce. In the domestic market, China Resources Vanguard not only faces competition from local supermarkets, but also faces competition from foreign retail giants such as Carrefour and Wal-Mart. At present, the problems existing in the inventory cost control of China Resources Vanguard Supermarket can be summarized as follows:

a) Lacking analysis of total inventory cost: According to the analysis of the definition of total inventory cost, it is composed of three aspects of ordering, holding inventory, out of stock, etc. In order to ensure effective control of inventory costs, it is necessary to make the analysis from the perspective of total inventory cost to ensure the lowest total inventory cost.

b) High cost of inventory and ordering: Through the above analysis of the inventory cost management of China Resources Vanguard Supermarket, we have concluded the main problems existing in the current situation. China Resources Vanguard has shortcomings in supplier management, which affects the control of inventory ordering costs. Judging from the current actual situation, China Resources Vanguard Supermarket should choose the lowest-priced supplier in the procurement process to reduce the sales price of its products. The responsibility of the purchase price management of China Resources Vanguard Supermarket mainly belongs to the purchasing department. The purchasing department is responsible for supplier management. During the management of procurement process, it also directly determines the purchase price. This method has improved procurement efficiency to a certain extent.

c) Out-of-stock cost is difficult to quantify: The outof-stock cost of China Resources Vanguard Supermarket is difficult to measure. And it is difficult to be truly reflected in the financial statements of supermarkets. However, the adverse effects of out-of-stock costs tend to be greater. For large supermarket chains, many consumers go shopping because of the variety of products. They can realize onestop shopping. If there are frequent shortages or high stockout rates, it will inevitably lead to the loss of a large number of consumers. According to sample survey, the current shortage rate of China Resources Vanguard Supermarket is about $4 \%$, which is still far from the shortage rate of competitors in the local area. Therefore, China Resources Vanguard Supermarket needs to effectively control out-ofstock rate as soon as possible. It should ensure that in the out-of-stock management level, it can stand on the same starting line with competitors such as Carrefour and WalMart.

\section{Suggestions For CHINA RESOURCES VANGUARD'S INVENTORY COST CONTROL}

In view of the above analysis of the current situation of inventory cost management of China Resources Vanguard Supermarket and the existing problems, it is recommended that China Resources Vanguard Supermarket further strengthen the control of inventory cost and establish corresponding measures from the following aspects.

\section{A. Improving the Management Level of Total Inventory Cost}

The cost of holding and acquiring inventory and the cost of stock out-of-stock constitute the total cost of inventory of China Resources Vanguard Supermarket. Therefore, it is necessary for China Resources Vanguard Supermarket to effectively control the inventory cost on the basis of investigation and research and to understand the basic situation of inventory cost. And then, China Resources Vanguard Supermarket can strictly control the total inventory cost.

China Resources Vanguard Supermarket should comprehensively promote and implement the ABC classification method at all stages and links in managing the total inventory cost. The ABC classification method generally divides the total sales volume of products into three different proportions. This ratio is generally at around $7: 2: 1$. Through this arrangement, the key management of commodities accounted for the largest proportion is guaranteed, ensuring the control of total inventory cost.

\section{B. Strictly Controlling the Inventory Ordering Cost}

China Resources Vanguard Supermarket needs to further clarify its strategic cooperation with suppliers. Especially for some suppliers with large supply and long cooperation time, China Resources Vanguard Supermarket can directly sign a 
long-term strategic cooperation agreement with them to confirm the long-term strategic cooperation. This approach is conducive to ensuring that the supply of goods of China Resources Vanguard Supermarket is stable and effective. At the same time, it is necessary to strengthen the management of the order price. The inventory order cost is determined by the order price. At present, the management authority of the order price of China Resources Vanguard Supermarket is mainly concentrated in the procurement department. This excessive concentration of authority is not conducive to the management of the order price.

\section{Reducing the Out-of-stock Costs}

For China Resources Vanguard Supermarket, it is necessary to establish a complete logistics response process from the perspective of the company. The construction of China Resources Vanguard Supermarket logistics rapid response process should be carried out from purchase, acceptance, warehousing, shelf management, picking, distribution processing, packaging, sorting, shipping inspection, loading, distribution and other businesses. China Resources Vanguard can respond quickly in every link of the supply chain, which can improve logistics response time and speed.

In the safety stock setting, China Resources Vanguard can classify the materials with the $\mathrm{ABC}$ classification method. It can ensure that the safety stock setting is reasonable.

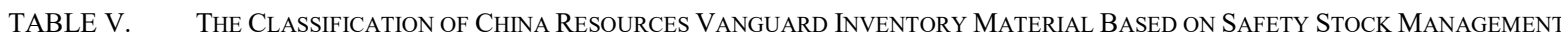

\begin{tabular}{|l|l|l|}
\hline classification & \multicolumn{1}{|c|}{ specific description } & \multicolumn{1}{|c|}{ Safety stock management strategy } \\
\hline Class A & $\begin{array}{l}\text { The value of such materials is high. The shortage of goods } \\
\text { will have great impact on the business management of the } \\
\text { enterprise; }\end{array}$ & $\begin{array}{l}\text { The management of safety stocks should be in } \\
\text { accordance with quantitative safety stock } \\
\text { management strategy; }\end{array}$ \\
\hline Class B & $\begin{array}{l}\text { The value of such materials is high. The shortage of goods has } \\
\text { greater impact on the operation and management of the } \\
\text { enterprise; }\end{array}$ & $\begin{array}{l}\text { The management of safety stocks should be in } \\
\text { accordance with regular safety stock } \\
\text { management strategies; }\end{array}$ \\
\hline Class C & $\begin{array}{l}\text { The value of such materials is general. The shortage of goods } \\
\text { has general impact on the management of the enterprise. }\end{array}$ & No safety stock management is performed. \\
\hline
\end{tabular}

According to the $\mathrm{ABC}$ classification management method as shown in "Table V", China Resources Vanguard Supermarket can divide its inventory materials into three categories: A, B, and C. The value of Class A materials is high. If the supermarket lacks Class A materials, it has a great impact on the operation and management of the enterprise. It should regularly manage safety stock according to safety stock management. The safety stock calculation is relatively accurate. Class $B$ materials have higher value. If the supermarket lacks Class B materials, it has a greater impact on the company's operation and management. The safety stock management is carried out. However, the safety stock management is more extensive. Class $\mathrm{C}$ materials are of general value. If the supermarket lacks Class $\mathrm{C}$ materials, it has a small impact on the operation and management of the enterprise. The safety stock is not set and the safety stock management is not performed.

\section{CONCLUSION}

Based on the analysis of the basic situation of inventory cost control of China Resources Vanguard Supermarket, the defects and shortcomings of the inventory cost control of the supermarket are found. At the same time, we can give positive and effective countermeasures to improve the inventory cost control.

In the process of controlling inventory costs, China Resources Vanguard Supermarket should fully grasp the basic conditions of the above three costs, and then control the total inventory cost within a reasonable range.

In the management of inventory ordering costs, China Resources Vanguard Supermarket needs to further strengthen procurement and supply management.
In order to improve the level of out-of-stock cost control, strengthen out-of-stock management, and save out-of-stock costs, China Resources Vanguard Supermarket needs to establish a fast replenishment system to ensure that the store's out-of-stock information can be delivered in the first time. At the same time, China Resources Vanguard Supermarket needs to make up the lack of goods in the first time, reducing the cost of out-of-stock.

In the control of inventory holding costs, China Resources Vanguard Supermarket needs to strengthen management from two aspects: inventory turnover rate and logistics distribution cost management.

\section{REFERENCES}

[1] F.W.Harris. Many Partsto Make at Ones[M]. Factoryahe:the Magazine of industry, 1913:28-29.

[2] Chakrabarty T. An EOQ Model for items with Weibull distribution eterioration,shortage and trended demand[J]. Computer\&Operations Research,1999, (26):649-657.

[3] J.Michalska, D.Szewieczek. The improvement of the quality management by the activity-based cost[J]. Journal of Achievements in Materials and Manufacturing Engineering, 2007,(1): 91.

[4] Zhou Xiaozhuang. Research on JIT Method of Inventory Cost Control of Manufacturing Enterprise [D]. Shanghai: Tongji University; 2007: 45-47. (in Chinese)

[5] Li Jing. Inventory Accounting Measurement Based on $\mathrm{ABC}$ Classification[J]. Economic Research, 2011, (9): 71-72. (in Chinese)

[6] Dong Hui. Design and Application of Inventory Management Model Based on Excel Function [J]. Finance and Accounting Monthly.2013(3):91-94. (in Chinese)

[7] Chen Shuangshuang, Tong Xuezhi. Inventory Cost Management and Control of Chain Supermarket Based on Cost Analysis [J]. Friends of Accounting, 2012: (11): 65-67. (in Chinese) 
[8] Wang Xin. Research on Inventory Cost Control of HQ Chain Supermarket [D]. Heilongiiang Bayi Agricultural University, 2016. (in Chinese)

[9] Liao Dongsheng, Liang Benguang. Research on Wal-Mart Inventory Cost Management [J]. Friends of Accounting, 2017(11): 33-36(in Chinese) 